\title{
Öğretmenlerin Benimsedikleri Eğitim Felsefelerinin Çeşitli Değişkenler Açısından İncelenmesi
}

\section{Analysis of Education Philosophies Adopted by Teachers in terms of Different Variables}

\author{
Okay DEMIR ${ }^{1}$ Seda AKTI ASLAN ${ }^{2}$
}

\begin{tabular}{|c|c|}
\hline $\begin{array}{l}\text { Anahtar Kelimeler } \\
\text { Ĕgitim Felsefeleri, } \\
\ddot{O ̈ g r e t m e n l e r, ~} \\
\text { Eğitim Inançlarl, } \\
\text { Felsefe, } \\
\text { Ögretmen Görüşleri. }\end{array}$ & 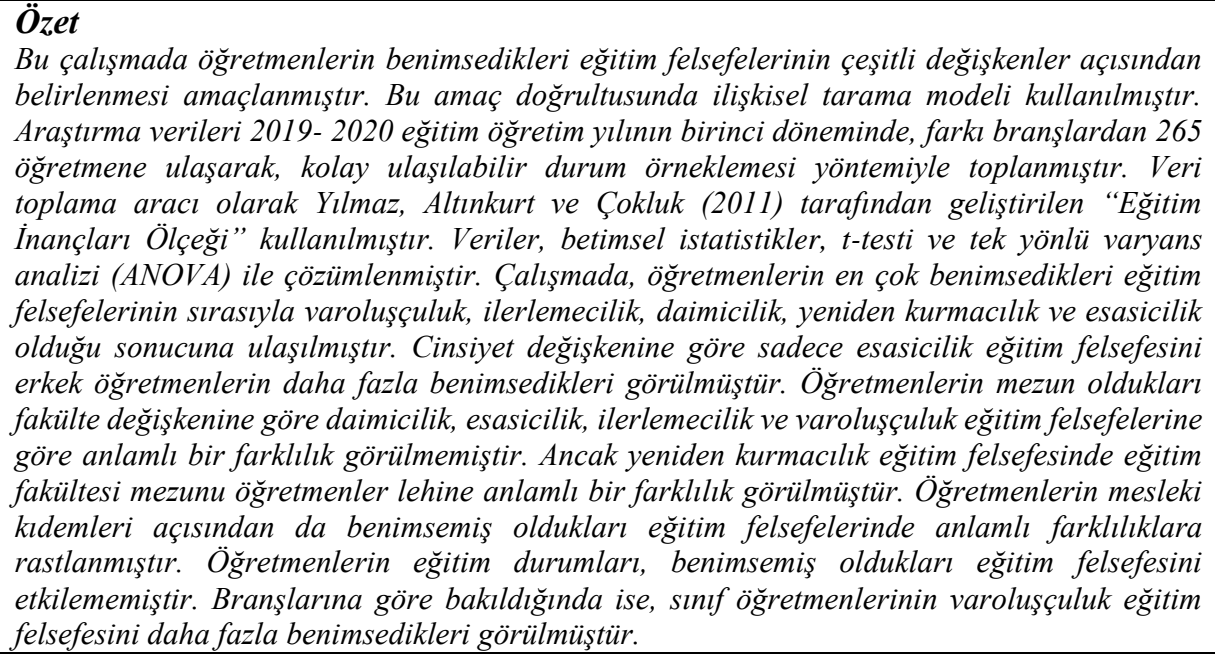 \\
\hline $\begin{array}{l}\underline{\text { Key Word }} \\
\text { Education } \\
\text { Philosophies, } \\
\text { Teachers, } \\
\text { Education Beliefs, } \\
\text { Philosophy, } \\
\text { Teacher Views. }\end{array}$ & $\begin{array}{l}\text { Abstract } \\
\text { The purpose of this research is to determine the education philosophies adopted by teachers in } \\
\text { terms of different variables. For this purpose, the correlational survey model, was used in the } \\
\text { research process. The research data were collected in the first semester of the } 2019-2020 \\
\text { academic year by reaching } 265 \text { teachers from different departments by using convenience } \\
\text { sampling method. 'Education Belief Scale' developed by Yllmaz, Altinkurt, and Çokluk (2011) } \\
\text { was used to collect data. The collected data were analyzed through descriptive statistics, t-test, } \\
\text { and One Way Variance Analysis (ANOVA). According to the results of the research, teachers } \\
\text { adopted these education philosophies respectively: Existentialism, Progressivism, } \\
\text { Perennialism, Re-Constructionism, and Essentialism. It was determined that, in terms of the } \\
\text { variable of gender, male participants only adopted essentialism philosophy more when } \\
\text { compared to females. In terms of the variable of the faculty from which the participants } \\
\text { graduated, there was no meaningful difference between perennialism, essentialism, } \\
\text { progressivism, and existentialism education philosophies. However, it was determined that } \\
\text { there was a meaningful difference in re-constructivism education philosophy in favor of the } \\
\text { teachers who graduated from education faculty. There were meaningful differences in the } \\
\text { adopted education philosophies in terms of the variable of professional seniority. The education } \\
\text { level of teachers didn't affect the education philosophy they adopted. When the variable of } \\
\text { specialty was taken into consideration, it was observed that classroom teachers adopted } \\
\text { education philosophy more than the others. }\end{array}$ \\
\hline
\end{tabular}

\section{Atıf için: For Citation}

Demir, O., \& Aktı-Aslan, S. (2021). Öğretmenlerin benimsedikleri eğitim felsefelerinin çeşitli değişkenler açısından incelenmesi. Muğla Sıtkı Koçman Üniversitesi Eğitim Fakültesi [MSKU Journal of Education ], 8(1), 307-321. DOI: 10.21666/muefd.842880

Received: 18.12.2020 Accepted: 31.03.2021 Published: 01.05.2021

\footnotetext{
${ }^{1}$ Millî Ĕ̆itim Bakanlı̆̆l, okay4425@gmail.com., ORCID: 0000-0001-8033-3355

${ }^{2}$ Millî Ĕgitim Bakanlığl, sedakti@gmail.com., ORCID: 0000-0001-9345-6194
} 
Her toplum kendi ihtiyacı olan insan gücünü çeşitli anlayışlar gözeterek yetiştirmektedir. Farklı eğitim süreçlerinden geçen bireylere "Bilgiyi nasıl edindirebiliriz?" sorusu eğitimin temel gayesi olmuştur. Bu doğrultuda hayatı boyunca insanın hangi amaca, hangi yöntemle gitmesi gerektiğini ancak felsefenin değerleri belirleyebilir. Eğitim, felsefenin deneyim alanı (Dewey, 2004) aynı zamanda bir alt sistemi olarak da düşünülebilir. Erişen (2012) felsefeyi "evrenin yapı ve düzeni, yaşamın anlam ve amacı, bilginin kaynağı ve güvenirlik derecesi, iyi, güzel ve doğrunun ne olduğu, başka bir deyişle, bilgi, varlık ve değerlere ilişkin soru ve sorunlarla ilgili bir uğraş alanı" olarak tanımlamaktadır. Felsefe, kim olduğumuzu, inanç ve değerlerimizin neler olduğunu ve ne yapmak istediğimizi anlamamızı sağlar ve gerçeğin anlamlandırılması sürecidir (Demirel, 2003). Aynı zamanda felsefe gerçeği bir bütün olarak ele alır. Bu yüzden felsefe ile eğitim bir bütündür (Şişman, 2008; Yayla, 2009). Brauner ve Burns (1965) eğitim sürecinde felsefenin göz ardı edilemeyeceğini söylemektedirler. (Akt. Kumral, 2015). Onlara göre eğitimin felsefi yanı göz ardı edildiğinde, köpeği olmayan bir görme engellinin durumuna düşülür. Bu durumda eğitim ile felsefe arasında doğan ilişki eğitim felsefesini ortaya çıkarmıştır. Felsefe eğitimöğretim sürecinde özellikle hedeflerin belirlenmesi aşaması olmak üzere tüm aşamalarda bir ölçüt işlevi görür (Ornstein ve Hunkins, 2016). Her eğitim felsefesinin temel aldığı bir felsefi akım vardır. Bu akıma göre eğitimin tüm süreçlerini ve öğretim ortamlarını şekillendiren disiplin eğitim felsefesi olarak tanımlanmaktadır (Aslan, 2014). Eğitim felsefesi birçok boyutta eğitim sürecini etkiler. Bu aşamada öncelikle eğitim sürecinin toplumun ve bireyin ihtiyaçlarına uygun olup olmadığını denetler (Baş, 2015). Ardından amaçların belirlenmesi, eğitim programının şekillenmesi ve öğretim metotları ile eğitim ortamı arasında ilişki kurulmasını sağlar (İsmailoğlu \& Zorlu, 2018). Başka bir deyişle eğitim felsefesi, eğitim, politika ve uygulamalarına yön veren varsayım, inanç, karar ve ölçütleri inceleyen fikir ve kavramlar bütünü (Biçer \& Özel, 2013) ve aynı zamanda eğitim amacını tartışan, eğitimle ilgili yapılan faaliyetleri belirleyen ve eğitim küresini oluşturan kavramları çözümleyen felsefi bir disiplin olarak tanımlanmaktadır (Coşkun, 2019).

Felsefenin eğitime birçok yönden katkısı vardır. Bu katkılar: "Eğitim hedeflerinin belirlenmesinde ve iç tutarlılığının kontrolünde felsefenin yön gösterici olması, eğitim durumlarının düzenlenmesi ve işe koşulmasında felsefeden yararlanılması, sınama durumlarının düzenlenmesi ve denetlenmesinde felsefenin ölçütler takımı olarak kullanılabilmesi, temele alınan felsefelere göre eğitim sisteminin işleyip işlemediğinin denetlenebilmesi” (Sönmez, 2014:50-54) şeklinde sıralanabilir ve bu iki alan böylece birbirini bütünler. Bütüncü ve tutarlı bir bakış açısı oluşturmak amacıyla bir araya gelen bu kavramlar (Arslanoğlu, 2018) eğitim faaliyetlerine yön verir.

\section{Eğitim Felsefeleri ve Öğretmenlerin Rolü}

İlgili alan yazın incelendiğinde eğitim felsefelerinin daimicilik, ilerlemecilik, yeniden kurmacıllk, doğalcılık ve varoluşçuluk şeklinde başlıklandırıldığını görebiliriz (Wiles ve Bondi, 2007). Ornstein ve Hunkins (2012) ise eğitim felsefelerini daimicilik, esasicilik, ilerlemecilik ve yeniden kurmacılık şeklinde sınıflandırmaktadır. Yine literatüre dayanarak eğitim felsefesi ile ilgili akımları bilgiye, öğretmene ve öğrenciye bakış açılarına göre iki ana gruba ayırmak mümkün olabilir. Realist, daimici ve esasici akımlar ilk grupta; pragmatik, ilerlemeci, yeniden kurmacı, varoluşçu, hümanist akımlar ise ikinci grupta toplanabilir (Kumral, 2015). Realist, daimici ve esasici akımlarda bilginin mutlak ve değişmez olduğu söz konusudur. Öğretmen bilgiyi bilen kişi olarak aktaracak olandır. Aynı zamanda uzman kişi olarak sınıf içinde karar vermeye yetkili tek kişidir (Yılmaz, Altınkurt\& Çokluk, 2011). Öğrenciye düşen ise kendilerine verilen bilgiyi öğrenmektir (Demirel, 2012; Sönmez, 2009). Yine bu akımlarda eğitim, yaşama hazırlık sürecidir ve amaç kültürel mirası aktarmak, bilgili ve iyi vatandaşlar yetiştirmektir. Pragmatik, ilerlemeci, yeniden kurmacı, varoluşçu ve hümanist akımlarda ise bireyin deneyimleri ön planda ve önemlidir (Hamrah, 2012). Eğitim ortamlarının öğrencinin ihtiyaç ve beklentilerine uygun şekilde yaratılması gerekir. Öğrencilerin değişimlere ayak uyduracak şekilde geleceğe yönelik eğitilmesi önemlidir. Tek bir doğru veya evrensel bir öğrenme yöntemine inanmadıkları için, derslerin içeriğinin ve eğitim yaşantılarının tek tek bireylerin ilgi ve ihtiyaçlarına göre düzenlenmesi gerektiği savunulmaktadır (Meral, 2014; Terzi, 2010). Bu durumda öğretmenin otoriter öğretici rolü de ortadan kalkmakta ve eğitim sürecinin merkezinde olan bireye rehberlik rolü ortaya çıkmaktadır.

Hızlı değişim sürecinde olan bireylerin adaptasyonunu sağlamadaki en önemli rollerden biri öğretmene düşmektedir. Çünkü öğretmen, eğitime yön verip, eğitim hedeflerini belirleyen ve uygulamalara yol gösteren bir disiplin olarak görülen eğitim felsefesi ile öğrenci arasındaki bağı kuran kişidir (Biçer, Er 
\& Özel, 2013). Öğretmenler benimsedikleri felsefi inançlar doğrultusunda yetiştirdikleri bireyleri olduğu kadar çevrelerini de etkilemektedirler. Alan yazın incelendiğinde öğretmenlerin farklı eğitim felsefelerini benimsedikleri hatta bazılarının tek bir eğitim felsefesi yerine birden çok eğitim felsefesini

benimsedikleri de görülmektedir (Doğanay \& Sarı, 2003; Duman \&Ulubay, 2008). Yapılan bu çalışmanın farklı branşlardan öğretmenlerin benimsemiş oldukları eğitim felsefelerini ortaya koymak adına önemli olduğu düşünülmektedir. Çünkü öğretmenlerin kullanacakları öğretim yöntemlerine karar verebilmeleri için belli bir eğitim felsefesine sahip olmaları gerekmektedir (Campbell, 1990). Ayrıca öğretmenlerin cinsiyet, mezun olunan fakülte, mesleki kıdem, eğitim durumu ve branşlarına göre benimsemiş oldukları eğitim felsefeleri arasındaki farklılaşmanın da incelenerek açıklığa kavuşturulması hedeflenmiştir. Her öğretmenin eğitim öğretime ilişkin farklı bakış açıları vardır. Öğrenmenin en önemli unsurunun öğretmen olduğu düşünüldüğünde, benimsediği eğitim felsefesinin de önemi açığa çıkmaktadır. Öğretmenin bakış açısı ve inanışları sınıf içerisinde gerçekleştirilen öğretim faaliyetlerini doğrudan veya dolaylı yoldan etkileyebilmektedir (Doğanay \& Sarı, 2003). Çünkü öğretmenlerin benimsedikleri farklı inanışlar herkes için geçerli olan eğitim programının farklı biçimlerde uygulanmasına neden olabilir (Hayırsever \& Oğuz, 2017). Ayrıca eğitim felsefesi olmadan öğretmenlerin eğitim süreçlerindeki tartışmaları, yapılan araştırmaları ve uygulamaları anlamlandırabilmeleri oldukça zordur (Gosselin, 2007; Winc, 2012). Bu nedenler öğretmen adayları açısından eğitim felsefelerinin önemini de ortaya koymaktadır. Eğitim fakültelerinde lisans programına eğitim felsefesi dersi konularak öğretmenlerin mesleğe başlamadan önce felsefi akımlara hâkim olmaları ve mesleğe başladıklarında bunu hedef kitleye uygulayacakları programlara yansıtmaları beklenmektedir (Aslan, 2014). Bu zorunlu ders kapsamında öğretmen adaylarına eğitim ve felsefe ilişkisi, eğitimi etkileyen felsefi akımları ve bu akımların Türkiye Cumhuriyeti eğitim sistemine etkileri gibi içerikler sunulmaktadır. Ancak bazı öğretmen yetiştiren kurumların programlarına bakıldığında felsefe ve eğitim felsefesi gibi derslerin yer almadığ1 görülmektedir (Yılmaz, 2017). Bu durum da Topçu'nun (2014) "Felsefesi olmayan milletin mektebi olamaz" düşüncesini akıllara getirmektedir.

$\mathrm{Bu}$ çalışma kapsamında da öğretmenlerin benimsedikleri eğitim felsefelerinin çeşitli değişkenler açısından incelenmesi amaçlanmış ve aşağıdaki sorulara yanıtlar aranmıştır;

1. Öğretmenlerin benimsedikleri eğitim felsefeleri nelerdir?

2. Öğretmenlerin benimsedikleri eğitim felsefeleri cinsiyet, mezun olunan fakülte, mesleki kıdem, eğitim durumu ve branş değişkenine göre farklılaşmakta mıdır?

\section{Yöntem}

Öğretmenlerin benimsedikleri eğitim felsefelerini çeşitli değişkenler açısından belirlemeyi amaçlayan bu çalışmada ilişkisel tarama modeli kullanılmıştır. İlişkisel tarama modeli, değişkenler arası ilişkileri açıklamak, ilişki düzeyini tanımlamak ve muhtemel sonuçları tahmin etmek amacıyla kullanılabilir (Tekbiyık, 2014).

\section{Çalışma Grubu}

2019-2020 eğitim öğretim yılının birinci döneminde gerçekleştirilen bu çalışmada, kolay ulaşılabilir durum örneklemesi yoluyla 265 öğretmene ulaşılmış; ancak diğer öğretmen branşları bazında katılımın çok az olması ve hatalı/eksik olarak doldurulan formlar da göz önüne alındığında analize 240 öğretmenin dâhil edilmesine karar verilmiştir. Öğretmenlere ait demografik veriler Tablo 1'de verilmiştir.

Tablo 1'e göre, öğretmenlerin 151'i (\%62,9) kadın, 89'u (37,1) erkektir. Öğretmenlerin 175'i $(\% 72,9)$ eğitim fakültesi, 65 'i $(27,1)$ diğer fakültelerden mezundur. Mesleki kıdemleri bakımından öğretmenlerin 46's1 (\%19,2) 1-5 y1l, 59'u (\%24,6) 6-10 y1l, 61'i $(\% 25,4)$ 11-15 y1l, 35'i $(\% 14,6)$ 16-20 y1l ve 39'u $(\% 16,3) 21$ ve üstü mesleki kıdeme sahiptir. Eğitim durumu bakımından öğretmenlerin 169 'u $(\% 70,4)$ lisans, 57'si $(\% 23,8)$ yüksek lisans ve 14 'ü $(\% 5,8)$ doktora mezunudur. Branş bakımından öğretmenlerin 66'sı (\%27,5) Sınıf öğretmeni, 67'si (27,9) Bilişim teknolojileri öğretmeni, 61'i (\%25,4) Türkçe ve 46's1 $(\% 19,2)$ Matematik öğretmenidir. 
Tablo 1

Öğretmenlere Ait Demografik Veriler

\begin{tabular}{|c|c|c|c|}
\hline Değiş̧kenler & Grup & $f$ & $\%$ \\
\hline \multirow{3}{*}{ Cinsiyet } & Kadın & 151 & 62,9 \\
\hline & Erkek & 89 & 37,1 \\
\hline & Toplam & 240 & 100 \\
\hline \multirow{3}{*}{ Mezun Olunan Fakülte } & Eğitim Fakültesi & 175 & 72,9 \\
\hline & Diğer & 65 & 27,1 \\
\hline & Toplam & 240 & 100 \\
\hline \multirow{6}{*}{ Mesleki Kıdem } & 1-5 Yil & 46 & 19,2 \\
\hline & 6-10 Y1l & 59 & 24,6 \\
\hline & $11-15$ Yil & 61 & 25,4 \\
\hline & $16-20$ Yil & 35 & 14,6 \\
\hline & 21 Y1l ve üstü & 39 & 16,3 \\
\hline & Toplam & 240 & 100 \\
\hline \multirow{4}{*}{ Eğitim Durumu } & Lisans & 169 & 70,4 \\
\hline & Yüksek lisans & 57 & 23,8 \\
\hline & Doktora & 14 & 5,8 \\
\hline & Toplam & 240 & 100 \\
\hline \multirow{5}{*}{ Branş } & Sınıf öğretmeni & 66 & 27,5 \\
\hline & Bilişim Teknolojileri öğretmeni & 67 & 27,9 \\
\hline & Türkçe öğretmeni & 61 & 25,4 \\
\hline & Matematik öğretmeni & 46 & 19,2 \\
\hline & Toplam & 240 & 100 \\
\hline
\end{tabular}

\section{Veri Toplama Araçları}

Araştırma verileri 2019-2020 eğitim-öğretim yılı birinci döneminde toplanmıştır. Bu çalışmada, öğretmenlerin benimsedikleri eğitim felsefelerini belirlemek amacıyla "Eğitim İnançları Ölçeği" kullanılmıştır. Eğitim İnançları Ölçeği Yılmaz, Altınkurt ve Çokluk (2011) tarafından geliştirilmiş olup "Kesinlikle katılıyorum" seçeneğinden "Kesinlikle katılmıyorum" seçeneğine doğru 5'li Likert tipindedir. Ölçek "daimicilik", "esasicilik", "ilerlemecilik", "yeniden kurmacıllk" ve " varoluşçuluk" felsefelerini içeren 40 maddeden ve beş eğitim felsefesinden oluşmaktadır. Ölçekte yer alan maddelerin faktör yük değerleri 0.42 ile 0.74 ; madde toplam korelasyonları 0.22 ile 0.90 ; güvenirlik katsayıları ise 0.70 ile 0,91 arasında değişmekte ve ölçeğin beş faktörlü yapısı, doğrulayıcı faktör analizi ile de doğrulanmaktadır. Bu değerlere göre ölçeğin geçerli ve güvenilir bir ölçme aracı olduğu söylenebilir.

\section{Verilerin Analizi}

Ölçek aracılığıyla toplanan verilerin normal dağılıma uygunluğunu belirlemek amaciyla öncelikle basıklık ve çarpıklık katsayılarına bakılmıştır. Basıklık ve çarpıklık katsayılarının -1 ve +1 aralığında olmasından dolayı verilerin normal dağıldığı kabul edilmiştir (Büyüköztürk, 2012). Öğretmenlerin eğitim felsefelerini benimseme durumlarını ortaya koymak için betimsel istatistiklerden yararlanılmıştır. Ölçeğin alt basamaklarından alınan puanın yüksek olması, cevaplayıcıların o basamaktaki eğitim felsefesini benimsediğini, düşük olması ise, söz konusu felsefeye olan inancının az olduğunu göstermektedir. Öğretmenlerin eğitim felsefelerini benimseme düzeylerindeki farklılaşmayı ortaya koymada cinsiyet ve mezun olunan yükseköğretim kurumu için bağımsız örneklem t testi; mesleki kıdem, eğitim durumu ve branşa göre farklılaşmayı belirlemek için ise tek yönlü varyans analizi (ANOVA) kullanılmıştır. Tek yönlü varyans analizi sonucunda manidar çıkan F değerleri için, farkın 
kaynağını belirlemek üzere, varyansların homojen dağılıp dağılmaması durumlarına göre LSD (homojenlik) ve Dunnett's C (homojenliğin olmadığı yerde) Testi kullanılmıştır. Analizler sonucu

istatistiksel olarak farklılık bulunan durumlarda, farklılığın derecesi eta-kare (ๆ2) etki büyüklüğü hesaplanarak belirlenmiştir.

\section{Bulgular}

\section{Birinci Alt Probleme İlişkin Bulgular}

"Öğretmenler en çok hangi eğitim felsefelerini benimsemektedirler?" sorusuna yönelik olarak öğretmenlerin ölçeklere verdikleri yanıtlar üzerinden hesaplanan aritmetik ortalama, standart sapma değerleri ve cevapların düzeyi Tablo 2'de verilmiştir:

Tablo 2

Öğretmenlerin Ölçeğe Verdikleri Yanıtlara Göre Hesaplanan Ortalama ve Standart Sapma Puanları

\begin{tabular}{lllll}
\hline & Alt Boyutlar & $\boldsymbol{x}$ & $\boldsymbol{S}$ & Düzey \\
\cline { 2 - 5 } Eğitim Felsefesi & Daimicilik & 4,01 & 0,86 & Katıliyorum. \\
İnançları & Esasicilik & 2,68 & 0,88 & Kismen katıliyorum. \\
& İlerlemecilik & 4,32 & 0,40 & Kesinlikle katıliyorum. \\
& Yeniden kurmacılık & 3,98 & 0,84 & Katıliyorum. \\
& Varoluşçuluk & 4,55 & 0,56 & Kesinlikle katıliyorum. \\
\hline
\end{tabular}

Tablo 2 incelendiğinde öğretmenlerin sirasıyla Varoluşçuluk $(\bar{x}=4,55)$, İerlemecilik $(\overline{\mathrm{x}}=4,32)$, Daimicilik $(\overline{\mathrm{x}}=4,01)$, Yeniden kurmac1lık $(\overline{\mathrm{x}}=3,98)$ ve Esasicilik $(\overline{\mathrm{x}}=2,68)$ felsefelerini benimsedikleri söylenebilir.

\section{İkinci Alt Probleme İlişkin Bulgular}

Çalı̧̧manın ikinci alt problemi olan "Öğretmenlerin benimsedikleri eğitim felsefeleri cinsiyet, mezun olunan fakülte, mesleki kıdem, eğitim durumu ve branş değişkenlerine göre farklılaşmakta mıdır?" sorusuna yönelik olarak öğretmenlerin ölçeklere verdikleri yanıtlar cinsiyet ve mezun olunan fakülte değişkenleri için t testi; mesleki kıdem, eğitim durumu ve branş değişkenleri için Varyans analizi (Anova) yapılarak belirlenmiştir. Öğretmenlerin benimsedikleri eğitim felsefelerinin cinsiyet değişkenine göre $t$ testi sonuçları Tablo 3'te gösterilmektedir.

Tablo 3

Öğretmenlerin Benimsedikleri Ĕ̈itim Felsefelerinin Cinsiyet Değişkenine Göre T Testi Sonuçları

\begin{tabular}{|c|c|c|c|c|c|c|c|c|}
\hline & Cinsiyet & $\mathrm{N}$ & $\bar{x}$ & $s$ & $\mathrm{sd}$ & $\mathrm{t}$ & $\mathrm{P}^{*}$ & $\eta 2$ \\
\hline \multirow{2}{*}{ Daimicilik } & Kadın & 151 & 3,98 & 0,85 & 238 & $-1,16$ & ,886 & \\
\hline & Erkek & 89 & 4,07 & 0,88 & & & & \\
\hline \multirow{2}{*}{ Esasicilik } & Kadın & 151 & 2,55 & 0,78 & 238 & $-4,58$ & ,004 & ,081 \\
\hline & Erkek & 89 & 2,83 & 0,99 & & & & \\
\hline \multirow{2}{*}{ İlerlemecilik } & Kadın & 151 & 4,35 & 0,66 & 238 & 1,29 & ,235 & \\
\hline & Erkek & 89 & 4,28 & 0,73 & & & & \\
\hline Yeniden & Kadın & 151 & 3,97 & 0,82 & 238 &,- 294 & 637 & \\
\hline Kurmacilık & Erkek & 89 & 4,00 & 0,87 & & & & \\
\hline \multirow{2}{*}{ Varoluşçuluk } & Kadın & 151 & 4,57 & 0,54 & 238 & ,869 & ,824 & \\
\hline & Erkek & 89 & 4,52 & 0,59 & & & & \\
\hline
\end{tabular}

$* \mathrm{p}<0.05$

Tablo 3 incelendiğinde, öğretmenler Daimicilik $\left(\mathrm{t}_{(238)}=-1,16, \mathrm{p}>.05\right)$, İlerlemecilik $\left(\mathrm{t}_{(238)}=1,29, \mathrm{p}>.05\right)$, Yeniden kurmac1lik $\left(\mathrm{t}_{(238)}=-0,294, \mathrm{p}>.05\right)$ ve Varoluşçuluk $\left(\mathrm{t}_{(238)}=0,869, \mathrm{p}>.05\right)$ felsefelerinde cinsiyete göre anlamlı bir farkl1l1k göstermezken; Esasicilik $\left(\mathrm{t}_{(238)}=-1,16, \mathrm{p}>.05\right)$, felsefesinde erkek öğretmenler lehine anlamlı bir farklılık olduğu görülmektedir. Esasicilik felsefesinin etki değerine bakıldığında, cinsiyet değişkeni açısından belirlenen etkinin "orta düzeyde" olduğu görülmektedir. Bu değere göre, cinsiyet değişkeni esasicilik boyutu için öğretmenlerin felsefi tercihleri üzerinde \%8,1'lik bir etki büyüklüğüne sahiptir. 
Öğretmenlerin benimsedikleri eğitim felsefelerinin fakülte değişkenine göre $t$ testi sonuçları Tablo 4 'te gösterilmektedir.

Tablo 4

Öğretmenlerin Benimsedikleri Eğitim Felsefelerinin Mezun Olunan Fakülte Değişkenine Göre T Testi Sonuçları

\begin{tabular}{|c|c|c|c|c|c|c|c|c|}
\hline & Fakülte & $\mathrm{N}$ & $\bar{x}$ & $s$ & sd & $\mathrm{t}$ & $\mathrm{p}^{*}$ & $\eta 2$ \\
\hline \multirow[t]{2}{*}{ Daimicilik } & Eğitim Fakültesi & 175 & 3,97 & 0,88 & 238 & $-1,81$ & 137 & \\
\hline & Diğer & 65 & 4,12 & 0,80 & & & & \\
\hline \multirow{2}{*}{ Esasicilik } & Eğitim Fakültesi & 175 & 2,65 & 0,85 & 238 & $-1,15$ &, 720 & \\
\hline & Diğer & 65 & 2,76 & 0,95 & & & & \\
\hline \multirow{2}{*}{ İlerlemecilik } & Eğitim Fakültesi & 175 & 4,32 & 0,66 & 238 & ,017 & ,475 & \\
\hline & Diğer & 65 & 4,33 & 0,71 & & & & \\
\hline \multirow{2}{*}{$\begin{array}{l}\text { Yeniden } \\
\text { Kurmacilık }\end{array}$} & Eğitim Fakültesi & 175 & 3,99 & 0,80 & 238 & ,246 & 015 & ,016 \\
\hline & Diğer & 65 & 3,97 & 0,91 & & & & \\
\hline \multirow{2}{*}{ Varoluşçuluk } & Eğitim Fakültesi & 175 & 4,55 & 0,55 & 238 &,- 448 & ,066 & \\
\hline & Diğer & 65 & 4,57 & 0,58 & & & & \\
\hline
\end{tabular}

$* \mathrm{p}<0.05$

Tablo 4 incelendiğinde, öğretmenler Daimicilik $\left(\mathrm{t}_{(238)}=-1,81, \mathrm{p}>.05\right)$, Esasicilik $\left(\mathrm{t}_{(238)}=-1,15, \mathrm{p}>.05\right)$, İlerlemecilik $\left(\mathrm{t}_{(238)}=-0,017, \mathrm{p}>.05\right)$ ve Varoluş̧̧uluk $\left(\mathrm{t}_{(238)}=-0,448, \mathrm{p}>.05\right)$ felsefelerinde mezun oldukları fakültelere göre anlamlı bir farkl1lık göstermezken; Yeniden kurmacılık $\left(\mathrm{t}_{(238)}=, 246, \mathrm{p}<.05\right)$, felsefesinde eğitim fakültesi mezunu öğretmenler lehine anlamlı bir farklılık olduğu görülmektedir. Yeniden kurmacılık felsefesinin etki değerine bakıldığında, mezun olunan fakülte değişkeni açısından belirlenen etkinin "küçük" olduğu görülmektedir. Bu değere göre, mezun olunan fakülte değişkeni, yeniden kurmacılık boyutu için, öğretmenlerin felsefi tercihleri üzerinde \%1,6'lik bir etki büyüklügüne sahiptir.

Öğretmenlerin benimsedikleri eğitim felsefelerinin mesleki kıdem değişkenine göre varyans analizi sonuçları Tablo 5'te gösterilmektedir.Tablo 5'te öğretmenlerin benimsedikleri eğitim felsefelerinin mesleki kıdem düzeyine göre ANOVA testi sonuçları incelendiğinde tüm eğitim felsefeleri açısından gruplar arasında anlamlı farklar olduğu görülmektedir. Daimicilik felsefesi açısından 1 ve 4 arasında kıdemi 4 olanlar lehine; 1 ve 5 arasında kıdemi 5 lehine; 2 ve 5 arasında kidemi 5 olanlar lehine; 3 ve 5 arasında kıdemi 5 olanlar lehine anlamlı farklar olduğu görülmektedir. Esasicilik felsefesi açısından 1 ve 4 arasında kıdemi 4 olanlar lehine; 1 ve 5 arasında kıdemi 5 olanlar lehine anlamlı farklar olduğu görülmektedir. İlerlemecilik felsefesi açısından sadece 2 ve 5 arasında kıdemi 5 olanlar lehine anlamlı bir fark olduğu görülmektedir. Yeniden yapılandırmacılık felsefesinde 1 ve 5 arasında kıdemi 5 olanlar lehine; 2 ve 5 arasında yine kıdemi 5 olanlar lehine anlamlı farklar olduğu görülmektedir. Varoluşçuluk felsefesinde 2 ve 5 arasında kıdemi 5 olanlar lehine; 3 ve 5 arasında kıdemi 5 olanlar lehine anlamlı farklar olduğu görülmektedir. Etki değerlerine bakıldığında, öğretmenlerin felsefi tercihleri üzerinde mesleki kıdem değişkeni açısından belirlenen etkinin esasicilik, ilerlemecilik ve varoluşçuluk boyutları için "küçük" düzeyde olduğu ve sırasıyla $\% 4,4, \% 4,2$ ve $\% 4,3$ 'lük etki büyüklüklerine sahip olduğu görülmektedir. Daimicilik ve yeniden kurmacılık felsefeleri açısından ise etki düzeylerinin "orta" düzeyde olduğu ve sırasıyla \%12,6 ve \%6,4'lük etki büyüklüklerine sahip olduğu görülmektedir. 
Tablo 5

Öğretmenlerin benimsedikleri ĕ̌itim felsefelerinin mesleki kıdem düzeyine göre varyans analizi sonuçları

\begin{tabular}{|c|c|c|c|c|c|c|c|c|c|c|c|c|}
\hline \multicolumn{5}{|c|}{ Betimsel İstatistikler } & \multicolumn{8}{|c|}{ ANOVA sonuçları } \\
\hline $\begin{array}{l}\text { Eğitim } \\
\text { Felsefeleri }\end{array}$ & $\begin{array}{l}\text { Mesleki } \\
\text { k1dem }\end{array}$ & $\mathrm{N}$ & $X$ & Ss & $\begin{array}{l}\text { Varyansın } \\
\text { Kaynağ1 }\end{array}$ & KT & sd & $\mathrm{KO}$ & $\mathrm{F}$ & $\mathrm{p}^{*}$ & $\begin{array}{l}\text { Anlaml1 } \\
\text { fark }\end{array}$ & $\eta 2$ \\
\hline \multirow{5}{*}{ 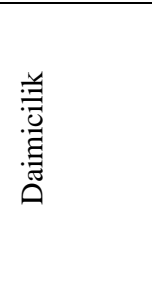 } & $(1)^{*}$ & 46 & 29,73 & 4,69 & Gruplararası & 590,464 & 4 & 147,616 & 8,449 & ,000 & $1-4,1-5$ & \multirow{5}{*}{, 126} \\
\hline & $(2)^{* *}$ & 59 & 31,94 & 4,01 & Grup içi & 4105,998 & 235 & 17,472 & & & $2-5,3-5$ & \\
\hline & $(3)^{* * *}$ & 61 & 31,88 & 4,41 & Toplam & 4696,463 & 239 & & & & & \\
\hline & $(4) * * * *$ & 35 & 33,02 & 4,00 & & & & & & & & \\
\hline & $(5) * * * * *$ & 39 & 34,87 & 3,50 & & & & & & & & \\
\hline \multirow{5}{*}{ 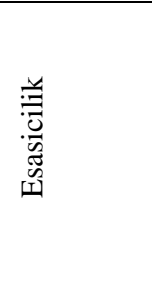 } & $(1)^{*}$ & 46 & 12,21 & 2,08 & Gruplararası & 99,605 & 4 & 24,901 & 2,715 & ,031 & $1-4,1-5$ & \multirow{5}{*}{,044 } \\
\hline & $(2)^{* *}$ & 59 & 13,57 & 3,32 & Grup içi & 2155,045 & 235 & 9,170 & & & & \\
\hline & $(3) * * *$ & 61 & 13,44 & 3,33 & Toplam & 2254,650 & 239 & & & & & \\
\hline & $(4) * * * *$ & 35 & 14,25 & 3,03 & & & & & & & & \\
\hline & $(5) * * * * *$ & 39 & 13,84 & 2,98 & & & & & & & & \\
\hline \multirow{5}{*}{ 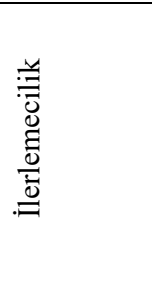 } & $(1)^{*}$ & 46 & 56,02 & 5,15 & Gruplararası & 256,270 & 4 & 64,068 & 2,550 & ,040 & $2-5$ & \multirow{5}{*}{,042 } \\
\hline & $(2)^{* *}$ & 59 & 55,23 & 4,88 & Grup içi & 5905,125 & 235 & 25,128 & & & & \\
\hline & $(3) * * *$ & 61 & 55,73 & 4,82 & Toplam & 6161,396 & 239 & & & & & \\
\hline & $(4) * * * *$ & 35 & 57,08 & 5,20 & & & & & & & & \\
\hline & $(5) * * * * *$ & 39 & 58,23 & 5,13 & & & & & & & & \\
\hline \multirow{5}{*}{ 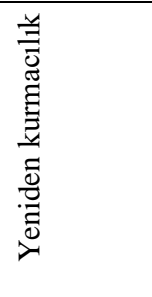 } & $(1)^{*}$ & 46 & 26,78 & 3,84 & Gruplararası & 263,249 & 4 & 65,812 & 4,002 & ,004 & $1-5,2-5$ & \multirow{5}{*}{,064 } \\
\hline & $(2)^{* *}$ & 59 & 27,25 & 3,97 & Grup içi & 3864,734 & 235 & 16,446 & & & & \\
\hline & $(3)^{* * *}$ & 61 & 27,95 & 4,22 & Toplam & 4127,983 & 239 & & & & & \\
\hline & $(4) * * * *$ & 35 & 28,02 & 4,23 & & & & & & & & \\
\hline & $(5) * * * * *$ & 39 & 30,05 & 3,97 & & & & & & & & \\
\hline \multirow{5}{*}{ 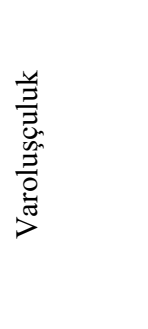 } & $(1)^{*}$ & 46 & 31,91 & 3,35 & Gruplararası & 87,101 & 4 & 21,775 & 2,667 & ,033 & $2-5,3-5$ & \multirow{5}{*}{,043 } \\
\hline & $(2)^{* *}$ & 59 & 31,35 & 2,68 & Grup içi & 1918,883 & 235 & 8,165 & & & & \\
\hline & $(3)^{* * * *}$ & 61 & 31,73 & 2,83 & Toplam & 2005,983 & 239 & & & & & \\
\hline & $(4) * * * *$ & 35 & 31,68 & 3,08 & & & & & & & & \\
\hline & $(5) * * * * *$ & 39 & 33,20 & 2,23 & & & & & & & & \\
\hline
\end{tabular}

Öğretmenlerin benimsedikleri eğitim felsefelerinin eğitim durumu değişkenine göre varyans analizi sonuçları Tablo 6'da gösterilmektedir. 
Tablo 6

Öğretmenlerin Benimsedikleri Eğitim Felsefelerinin Eğitim Durumu Değiş̧kenine Göre Varyans Analizi

Sonuçları

\begin{tabular}{|c|c|c|c|c|c|c|c|c|c|c|}
\hline \multicolumn{5}{|c|}{ Betimsel İstatistikler } & \multicolumn{6}{|c|}{ ANOVA sonuçları } \\
\hline Eğitim Felsefeleri & $\begin{array}{l}\text { Eğitim } \\
\text { Durumu }\end{array}$ & $\mathrm{N}$ & $X$ & Ss & $\begin{array}{l}\text { Varyansın } \\
\text { Kaynağ1 }\end{array}$ & KT & sd & $\mathrm{KO}$ & $\mathrm{F}$ & $\mathrm{p}^{*}$ \\
\hline \multirow{3}{*}{ 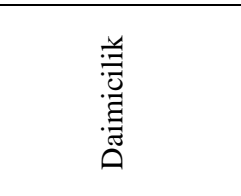 } & Lisans & 169 & 32,21 & 4,50 & Gruplararas1 & 6,205 & 2 & 3,102 & \multirow[t]{3}{*}{, 157} & \multirow[t]{3}{*}{, 855} \\
\hline & Y.Lisans & 57 & 32,03 & 4,09 & Grup içi & 4690,258 & 237 & 19,790 & & \\
\hline & Doktora & 14 & 31,57 & 5,15 & Toplam & 4696,463 & 239 & & & \\
\hline \multirow{3}{*}{ 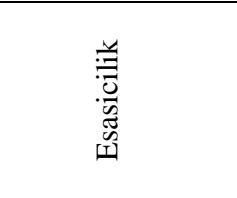 } & Lisans & 169 & 13,60 & 2,93 & Gruplararas1 & 19,567 & 2 & 9,783 & \multirow[t]{3}{*}{1,037} & \multirow[t]{3}{*}{,356 } \\
\hline & Y.Lisans & 57 & 12,96 & 3,35 & Grup içi & 2235,083 & 237 & 9,431 & & \\
\hline & Doktora & 14 & 13,07 & 3,49 & Toplam & 2254,650 & 239 & & & \\
\hline \multirow{3}{*}{ 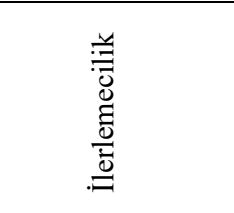 } & Lisans & 169 & 56,27 & 5,23 & Gruplararas1 & 27,125 & 2 & 13,562 & \multirow[t]{3}{*}{, 524} & \multirow[t]{3}{*}{,593 } \\
\hline & Y.Lisans & 57 & 55,94 & 4,76 & Grup içi & 6134,271 & 237 & 25,883 & & \\
\hline & Doktora & 14 & 57,50 & 4,51 & Toplam & 6161,396 & 239 & & & \\
\hline \multirow{3}{*}{ 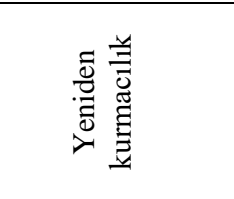 } & Lisans & 169 & 28,10 & 4,43 & Gruplararas1 & 27,835 & 2 & 13,917 & \multirow[t]{3}{*}{,804 } & \multirow[t]{3}{*}{,449 } \\
\hline & Y.Lisans & 57 & 27,29 & 3,20 & Grup içi & 4100,148 & 237 & 17,300 & & \\
\hline & Doktora & 14 & 28,07 & 4,08 & Toplam & 4127,983 & 239 & & & \\
\hline \multirow{3}{*}{ 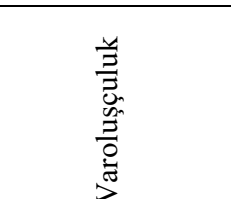 } & Lisans & 169 & 32,06 & 2,78 & Gruplararas1 & 16,736 & 2 & 8,368 & \multirow[t]{3}{*}{,997 } & \multirow[t]{3}{*}{,371 } \\
\hline & Y.Lisans & 57 & 31,43 & 3,04 & Grup içi & 1989,248 & 237 & 8,393 & & \\
\hline & Doktora & 14 & 31,92 & 3,60 & Toplam & 2005,983 & 239 & & & \\
\hline
\end{tabular}

$* \mathrm{p}<0.05$

Tablo 6 incelendiğinde öğretmenlerin eğitim durumları ile benimsedikleri eğitim felsefeleri arasında anlamlı farkların olmadığı görülmektedir.

Öğretmenlerin benimsedikleri eğitim felsefelerinin branş değişkenine göre varyans analizi sonuçları ise Tablo 7'de gösterilmektedir.

Tablo 7'de branş değişkenine göre öğretmenlerin eğitim felsefelerini benimseme düzeyleri incelendiğinde anlamlı farkın sadece Varoluşçuluk felsefesinde, sınıf öğretmenleri ve bilişim teknolojileri öğretmenleri arasında sınıf öğretmenleri lehine; sınıf öğretmenleri ve matematik öğretmenleri arasında yine sınıf öğretmenleri lehine olduğu görülmektedir. Etki değerine bakıldığında, öğretmenlerin felsefi tercihleri üzerinde branş değişkeni açısından, varoluşçuluk boyutunda belirlenen etkinin "küçük" olduğu görülmektedir. Bu değere göre, branş değişkeni varoluş̧̧uluk boyutu için öğretmenlerin felsefi tercihleri üzerinde \%4,2'lik bir etki büyüklüğüne sahiptir. 
Tablo 7

Öğretmenlerin benimsedikleri ĕgitim felsefelerinin branş değişkenine göre varyans analizi sonuçları

\begin{tabular}{|c|c|c|c|c|c|c|c|c|c|c|c|c|}
\hline \multicolumn{5}{|c|}{ Betimsel Istatistikler } & \multicolumn{8}{|c|}{ ANOVA sonuçları } \\
\hline $\begin{array}{l}\text { Eğitim } \\
\text { Felsefeleri }\end{array}$ & Branşlar & $\mathrm{N}$ & $X$ & Ss & $\begin{array}{l}\text { Varyansın } \\
\text { Kaynağı }\end{array}$ & KT & sd & $\mathrm{KO}$ & $\mathrm{F}$ & $\mathrm{p}^{*}$ & $\begin{array}{l}\text { Anlamlı } \\
\text { fark }\end{array}$ & $\eta 2$ \\
\hline \multirow{4}{*}{ 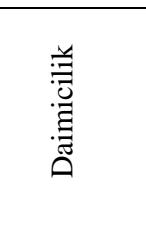 } & Sinıf öğrt. & 66 & 32,96 & 4,99 & Gruplararası & 92,083 & 3 & 30,694 & 1,573 & , 197 & & \\
\hline & BT öğrt. & 67 & 31,40 & 4,58 & Grup içi & 4604,380 & 236 & 19,510 & & & & \\
\hline & Türkçe öğrt. & 61 & 31,81 & 4,08 & Toplam & 4696,463 & 239 & & & & & \\
\hline & Matematik öğrt. & 46 & 32,43 & 3,64 & & & & & & & & \\
\hline \multirow{4}{*}{ 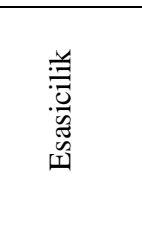 } & Sinıf öğrt. & 66 & 13,13 & 2,89 & Gruplararas1 & 39,789 & 3 & 13,263 & 1,413 & ,240 & & \\
\hline & BT öğrt. & 67 & 13,86 & 3,48 & Grup içi & 2214,861 & 236 & 9,385 & & & & \\
\hline & Türkçe öğrt. & 61 & 13,70 & 2,96 & Toplam & 2254,650 & 239 & & & & & \\
\hline & Matematik öğrt. & 46 & 12,82 & 2,74 & & & & & & & & \\
\hline \multirow{4}{*}{ 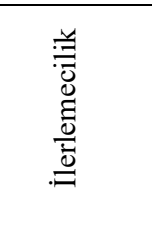 } & Sinıf öğrt. & 66 & 57,40 & 4,91 & Gruplararas1 & 124,817 & 3 & 41,606 & 1,627 & , 184 & & \\
\hline & BT öğrt. & 67 & 55,59 & 4,93 & Grup içi & 6036,579 & 236 & 25,579 & & & & \\
\hline & Türkçe öğrt. & 61 & 56,04 & 5,75 & Toplam & 6161,396 & 239 & & & & & \\
\hline & Matematik öğrt. & 46 & 55,91 & 4,40 & & & & & & & & \\
\hline \multirow{4}{*}{ 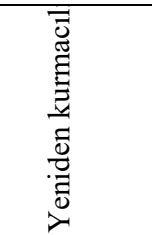 } & Sinıf öğrt. & 66 & 28,37 & 4,55 & Gruplararas1 & 70,889 & 3 & 23,630 & 1,375 &, 251 & & \\
\hline & BT öğrt. & 67 & 27,05 & 4,15 & Grup içi & 4057,095 & 236 & 17,191 & & & & \\
\hline & Türkçe öğrt. & 61 & 28,26 & 4,06 & Toplam & 4127,983 & 239 & & & & & \\
\hline & Matematik öğrt. & 46 & 28,00 & 3,57 & & & & & & & & \\
\hline \multirow{4}{*}{ 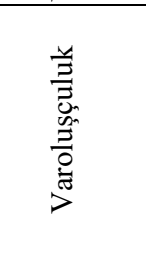 } & Sınıf öğrt.(1) & 66 & 32,84 & 2,54 & Gruplararas1 & 83,808 & 3 & 27,936 & 3,430 & ,018 & $1-2,1-4$ & \multirow{4}{*}{, 042} \\
\hline & BT öğrt.(2) & 67 & 31,55 & 2,87 & Grup içi & 1922,175 & 236 & 8,145 & & & & \\
\hline & Türkçe öğrt.(3) & 61 & 31,70 & 3,32 & Toplam & 2005,983 & 239 & & & & & \\
\hline & $\begin{array}{l}\text { Matematik } \\
\text { öğrt.(4) }\end{array}$ & 46 & 31,34 & 2,54 & & & & & & & & \\
\hline
\end{tabular}

\section{Tartışma, Sonuç ve Öneriler}

Öğretmenlerin benimsedikleri eğitim felsefelerini çeşitli değişkenler açısından belirlemeyi amaçlayan bu çalışmada, öğretmenlerin en çok benimsedikleri eğitim felsefelerinin sırasıyla varoluşçuluk, ilerlemecilik, daimicilik, yeniden kurmacılık ve esasicilik olduğu sonucuna ulaşılmıştır. Bu sonuç, alan yazındaki birçok araştırma sonuçları ile örtüşürken (Altınkurt, Yılmaz \&Aytunga, 2012; Çakmak, Bulut \& Taşkıran, 2016; Doğanay \&Sar1, 2003; Duman, 2008; Hayırsever \& Oğuz, 2017; Ilgaz, Bülbül \& Çuhadar, 2013; Kozikoğlu\& Erden, 2018; Kozikoğlu\& Uygun, 2018; Livinston\&McClain, 1995; Oğuz vd., 2014; Şahin, Tunca \& Ulubey, 2014; Uğurlu \&Çalmaşur, 2017) bazıları ile de örtüşmemektedir (Coşkun, 2019; Doğanay, 2011; Tekin \& Üstün, 2008). Buradan hareketle öğretmenlerin en çok varoluşçu ve ilerlemeci eğitim felsefelerini benimsedikleri, en az ise esasicilik eğitim felsefesini benimsedikleri görülmektedir. İlerlemeciliğin temelinde öğrenci merkezli bir anlayışın olması, esasiciliğin temelinde ise öğretmen merkezli bir anlayışın olması ve konu alanını merkeze alması öğretmenlerin felsefi görüşleri üzerinde etkili olabilmektedir. Ĕ̆itim öğretim sürecinde öğretmenin görevi eğitim ile felsefeyi harmanlayıp öğrenciye sunmaktır (Ağdacı, 2018). Bu araştırma sonucundan da hareketle, öğretmenlerin daha çok çağdaş eğitim felsefelerini benimsemeleri onların sınıf ortamında birey merkezli metodolojileri temel alarak, katı ve otoriter disiplin anlayışından uzak duracakları söylenebilir. Ayrıca öğretmenlerin Türkiye'de yürürlükte olan yapılandırmacı eğitim yaklaşımını benimsemiş olabileceklerinin de sonucu etkilediği söylenebilir (Berkant \& Özaslan, 2019). Alan yazın incelendiğinde bazı öğretmenlerin aynı anda birden fazla eğitim felsefesi benimseyebilecekleri de 
görülmüştür (Hayırsever \& Oğuz, 2017; Koçak, Ulusoy \& Önen, 2012). Koçak, Ulusoy ve Önen'in (2012) yaptıkları çalışmada kendilerini ilerlemeci olarak tanımlayan öğretmen adaylarının uygulamada esasici ve daimici eğitim felsefelerinin de etkisinde kaldıkları görülmüsstür. Bu durum, öğretmenlerin eğitim inançlarını tam olarak öğrenme ortamına yansıtamamaları veya eğitim inançlarına ilişkin yanlış algılara sahip olmaları ile açıklanabilir. Ornstein ve Hunkins (2016) ise tek bir felsefi anlayışın eğitim ve program ile ilgili doğru kararlar alınmasında mümkün olmadığını ve bu nedenle de bireyin ve toplumun ihtiyaçlarını karşılayabilmek için birden fazla eğitim felsefesini birleştirmenin gerekliliğini belirtmişlerdir.

Öğretmenlerin cinsiyetlerine göre; daimicilik, ilerlemecilik, yeniden kurmac1lık ve varoluşçuluk eğitim felsefelerinde manidar bir farklılık görülmemiştir. Ancak esasicilik eğitim felsefesini erkek öğretmenlerin daha fazla benimsedikleri görülmüştür. İlgili alan yazın incelendiğinde öğretmen veya öğretmen adaylarının cinsiyetlerinin, sahip oldukları eğitim felsefeleri üzerinde bir etki yaratmadığı sonuçlarına ulaşılmıştır (Aybek \& Aslan, 2017; Berkant \& Özaslan, 2019; Çelik ve Orçan, 2016; Yokuş, 2016). Buna rağmen Kumral (2015) erkek öğretmen adaylarının, öğretim ortamlarına yönelik daha geleneksel (pozitivist, modernist) düşündüğünü; kadın öğretmen adaylarının ise daha popüler (post pozitivist, yapılandırmacı) düşündüklerini belirtmiştir. Yine Ağdacı (2018) tarafından yapılan çalışmada erkek öğretmenlerin en fazla esasicilik eğitim felsefesini; kadın öğretmenlerin ise en fazla ilerlemecilik ve yeniden kurmacılık eğitim felsefelerini benimsedikleri görülmüştür. Buna karşın erkek fizik, kimya ve biyoloji öğretmenlerinin daha çok deneyselci anlayışta olduğunu gösteren çalışmalar da vardır (Taşkın, 2020).

Öğretmenlerin mezun oldukları fakülte değişkenine göre daimicilik, esasicilik, ilerlemecilik ve varoluşçuluk eğitim felsefelerine göre anlamlı bir farklılık görülmemiştir. Ancak yeniden kurmacılık eğitim felsefesinde eğitim fakültesi mezunu öğretmenler lehine anlamlı bir farklılık görülmüştür. Alan yazındaki bazı araştırmalar incelendiğinde, öğretmenlerin hizmet öncesi dönemde belirli bir eğitim felsefesi ile yetiştirilmemesine rağmen göreve başlarken belli görüş ve inanışlar geliştirdikleri görülmektedir (Austin \& Reinhardt, 1999; Pajares, 1992). Ekiz (2005) yapmış olduğu çalışmada üniversite birinci sınıf ve dördüncü sınıf öğrencilerinin eğitim inanışlarını incelemiş; öğrencilerin birinci sınıftayken en çok daimicilik ve esasicilik; dördüncü sınıfa geldiklerinde ise ilerlemecilik ve yeniden kurmacılık eğitim felsefelerini benimsediklerini belirtmiştir. Buradan hareketle eğitim fakültelerinde verilen eğitim felsefesi, eğitim psikolojisi, eleştirel düşünme ve insan ilişkileri gibi derslerin öğretmenlerin eğitim inançlarında çağdaş eğitim felsefelerine yönelme sağladığı düşünülebilir. Öğretmenlerin yeni öğretim programlarına uyum sağlayabilmeleri ve öğrencilerine aktarabilmeleri de yine benimsemiş oldukları eğitim felsefeleri ile ilişkilidir. Çünkü yapılandırmacı öğrenme kuramının ve ilerlemecilik eğitim felsefesinin temel ilkelerinin benimsenmesi ile ancak yeni öğretim programları uygulama aşamasına geçebilir (İçen, Tuncel \& Özay, 2018).

Öğretmenlerin mesleki kıdemlerine göre benimsedikleri eğitim felsefelerine bakıldığında; daimicilik, esasicilik, ilerlemecilik, yeniden kurmacılık ve varoluşçuluk eğitim felsefelerinin hepsinde gruplar arasında farklılıklar görülmüştür. Genellikle $16-20$ yıl ve 21 yıl üstü mesleki kıdeme sahip öğretmenlerin eğitim inançlarının diğer mesleki kıdem gruplarına göre daha fazla eğitim felsefelerini benimseyip uygulamaya koydukları görülmüştür. Ancak gruplar arasında mesleki kıdem açısından anlamlı farklılıklar görülse de etki düzeylerinin yüksek olmadığı sonuçlarına ulaşılmıştır. Alan yazın incelendiğinde çalışma sonuçlarını destekler şekilde kıdem yılı değişkeninin öğretmenlerin eğitim felsefelerinde belirleyici olmadığı sonuçlarına rastlamak mümkündür (Çoban, 2004; Karadağ, Baloğlu ve Kaya, 2009). Bunun aksine Ağdacı (2008) tarafından yapılan çalışmada öğretmenlerin mesleki kıdemlerine göre 5-9 y1l arasında görev yapanların en fazla ilerlemecilik eğitim felsefesini benimsedikleri; 15-20 yıl arasında görev yapanların ise en fazla daimicilik, esasicilik ve yeniden kurmac1lık eğitim felsefelerini benimsedikleri belirlenmiştir.

Öğretmenlerin eğitim durumlarına göre bakıldığında; lisans, yüksek lisans veya doktora mezunu olmalarının benimsemiş oldukları eğitim felsefelerini etkilemediği sonucuna ulaşılmıştır. Bu sonuç öğretmenlerin eğitim seviyesi arttıkça eğitim sürecindeki mesleki değerleri benimsemeleri ve daha çok çağdaş eğitim felsefelerini öğrenme-öğretme sürecine yansıtmaları gerektiği düşüncesi ile çelişmektedir. Tunca, Şahin ve Oğuz (2015) tarafından yapılan çalışma sonuçları da bu sonucu destekler niteliktedir.

Öğretmenlerin branşlarına göre benimsemiş oldukları eğitim felsefelerine bakıldığında; sınıf öğretmenlerinin varoluşçuluk eğitim felsefesini, bilişim teknolojileri ve matematik öğretmenlerine göre 
daha fazla benimsedikleri sonucuna ulaşılmıştır. Benzer şekilde Aslan'ın (2017) sınıf öğretmenleri ile yapmış olduğu çalışmada en fazla varoluşçu ve ilerlemeci, en az ise esasici eğitim felsefesini benimsedikleri görülmüştür. Yine Çoban (2004) sınıf öğretmenlerinin öğretme süreçlerinde en çok ilerlemeci düşündüğünü belirtmiştir. Daimicilik, esasicilik, ilerlemecilik ve yeniden kurmacılık eğitim felsefelerine bakıldığında ise branşlara göre bir farklılaşma görülmemiştir. Taşkın (2020) ile Kanatlı ve Schreglman'ın (2014) yapmış oldukları çalışmalarda öğretmenlerin branşlarının benimsemiş oldukları eğitim felsefelerini etkilemediği sonucuna ulaşılmıştır. Bu konuda alan yazında farklı araştırma sonuçlarına da rastlamak mümkündür. Yapılan bu çalışmalarda popüler düşüncelere sahip branşların İngilizce ve Türkçe öğretmenleri olduğunu (Kumral, 2015); Sosyal Bilgiler ve Okul Öncesi öğretmenlerinin ilerlemeci eğitim felsefesine sahip olduğunu (Duman, 2008); Matematik öğretmenlerinin her felsefi görüşü desteklerken Din Kültürü ve Ahlak Bilgisi öğretmenlerinin ise daha çok daimicilik görüşünü desteklediğini (Geçici \& Yapıc1, 2008) gösteren sonuçlara rastlamak mümkündür.

Yapılan bu çalışma sonuçlarından hareketle araştırmacılara yönelik geliştirilen önerilere aşağıda yer verilmiştir:

$>$ Uygulama alanında yer alan öğretmenlerin eğitim uygulamalarına, felsefi inançları yön vereceğinden, eğitim fakültelerinde eğitim felsefesi derslerinin kapsamı genişletilerek, öğretmenlerin bu alanda daha fazla farkındalık elde etmeleri sağlanabilir.

> Hizmet içi eğitim programlarına eğitim felsefeleri ile ilgili konular eklenerek, özellikle çağdaş eğitim felsefelerinin tanıtılması yönünde, öğretmenlerde farkındalık oluşturmaya çalış1labilir.

$>$ Farklı branşlarda, farklı veri toplama teknikleri kullanılarak öğretmenlerin eğitim felsefelerine eğilimleri tespit edilebilir.

$>$ Öğretmenlerin eğitim inançları ya da eğitim felsefelerini benimseme durumlarını farklı değişkenlerle ilişkilendirecek araştırmalar yapılabilir.

\section{Kaynakça}

Ağdacı, G. (2018). Öğretmenlerin eğitim felsefeleri eğilimi ile eleştirel düşünme becerileri arasındaki ilişski. (Yayınlanmamış Yüksek Lisans Tezi). Bartın Üniversitesi Eğitim Bilimleri Enstitüsü, Bartın.

Altınkurt, Y., Yılmaz, K., \& Oğuz, A. (2012). İlköğretim ve ortaöğretim okulu öğretmenlerinin eğitim inançları. On Dokuz Mayıs Üniversitesi Eğitim Fakültesi Dergisi, 31 (2), 1-19.

Arslanoğlu, İ. (2018). Eğitim felsefesi. (2.Baskı). Ankara: Nobel Yayınları

Aslan, Ö.M. (2014). Eğitim felsefesi dersinin okul öncesi öğretmen adaylarının felsefi tercihlerine ve eleştirel pedagojiye yönelik görüşlerine olan etkisi. Elektronik Sosyal Bilimler Dergisi, 13(48), 114.

Aslan, S. (2017). Sınıf öğretmenlerinin eğitim inançlarının çeşitli değişkenler açısından incelenmesi. Kastamonu Ë̆itim Dergisi, 25(4), 1453-1458.

Aybek, B., \& Aslan, S. (2017). Öğretmen adaylarının eleştirel düşünme eğilimleri ile benimsedikleri eğitim felsefelerinin çeşitli değişkenler açısından incelenmesi. Gaziantep University Journal of Social Sciences, 16(2), 373-385.

Baş, G. (2015). Öğretmenlerin eğitim felsefesi inançları ile öğretme-öğrenme anlayışları arasındaki ilişki. Eğitim ve Bilim, 40 (182), 111-126.

Berkant, H. G., \& Özaslan, D. (2019). Öğretmen adaylarının eğitim inançlarının çeşitli değişkenler açısından incelenmesi. Eskişehir Osmangazi Üniversitesi Sosyal Bilimler Dergisi, 20, 923-940.

Biçer, B., Er, H., \& Özel, A. (2013). Öğretmen adaylarının epistemolojik inançları ve benimsedikleri eğitim felsefeleri arasındaki ilişki. Journal Of Theory \& Practice in Education (Jtpe), 9(3), 229242.

Büyüköztürk. Ş. (2011). Sosyal bilimler için veri analizi el kitabı. Ankara: Pegem Akademi Yayınları.

Tekbıyık, A. (2014). Eğitimde bilimsel araştırma yöntemleri (Ed. M.Metin). Illişkisel araştırma yöntemi (s.100-114). Ankara: Pegem Akademi Yayınları. 
Campbell, L. P. (1990). Philosophy, Methodology, Motivation, Learning. The Clearing House, 64(1), 2122.

Coşkun, M. K. (2019). Din kültürü ve ahlak bilgisi öğretmen adaylarının benimsedikleri eğitim felsefeleri. Anemon Muş Alparslan Üniversitesi Sosyal Bilimler Dergisi, 7(1), 93-98.

Çakmak, Z., Bulut, B., \& Taşkıran, C. (2016). Sosyal bilgiler öğretmen adaylarının eğitim inançlarına yönelik görüşlerinin çeşitli değişkenler açısından incelenmesi. Abant İzzet Baysal Üniversitesi Eğitim Fakültesi Dergisi, 16, 109-124.

Çelik, R., \& Orçan, F. (2016). Öğretmen adaylarının eğitim inançları üzerine bir çalışma. Eğitimde Kuram ve Uygulama, 12(1), 63-77.

Demirel, Ö. (2003). Kuramdan uygulamaya eğitimde program geliştirme. Ankara: Pegem Yayınc1lık.

Demirel Ö. (2012). Eğitimde Program Geliştirme. Ankara: Pegem.Yayınc1lık.

Dewey, J. (2004). Demokrasi ve eğitim. (Çev.T. Göbekçin) Ankara: Yeryüzü Yayınevi.

Doğanay, A., \& Sarı, M. (2003). İlköğretim öğretmenlerinin sahip oldukları eğitim felsefelerine ilişkin algılarının değerlendirilmesi. Türk Ĕ̈itim Bilimleri Dergisi 1 (3).0-0.

Doğanay, A. (2011). Hizmet öncesi öğretmen eğitiminin öğretmen adaylarının felsefi bakış açılarına etkisi. Eğitim ve Bilim, 36(161), 332-348.

Duman, B. (2008). Öğrencilerin benimsedikleri eğitim felsefeleriyle kullanıldıkları öğrenme strateji ve öğrenme stillerinin karşılaştırılması. Ç. Ü. Sosyal Bilimler Enstitüsü Dergisi, 17(1), 203-224.

Duman, B., \&Ulubey, Ö. (2008). Öğretmen adaylarının benimsedikleri eğitim felsefelerinin öğretim teknolojilerini ve interneti kullanma düzeylerine etkisi ile ilgili görüşleri. Muğla Sıtkı Koçman Üniversitesi Sosyal Bilimler Enstitüsü Dergisi, 20, 95-114.

Ekiz, D. (2005). Sınıf öğretmeni adaylarının eğitim felsefesi akımlarına ilişkin eğilimlerinin karşılaştırılması. On dokuz Mayıs Üniversitesi Eğitim Fakültesi Dergisi, 19, 1-11.

Erişen, Y. (2012). Eğitimin felsefi temelleri. Ankara: Pegem Yayınc1lık.

Geçici, S., \& Yapıcı, Ş. (2008). İlköğretim öğretmenlerinin eğitim felsefesiyle ilgili görüşleri. Afyon Üniversitesi Eğitimbilimleri Dergisi, 1(2), 57-64.

Gosselin, C. (2007). Philosophy and the role of teacher reflections on constructing gender. Educational Foundations, 21 (3/4), 39-57.

Hamrah, Z. S. (2012). Role of virtual education in higher education from the view of existence philosophy. Journal of Social Sciences, 8 (2), 207-215.

Hayırsever, F., \& Oğuz, E. (2017). Öğretmen adaylarının eğitim inançlarının eleştirel düşünme eğilimlerine etkisi. Abant İzzet Baysal Üniversitesi Ĕgitim Fakültesi Dergisi, 17 (2), 757-778.

Ilgaz, G., Bülbül, T., \& Çuhadar, C. (2013). Öğretmen adaylarının bireysel yenilikçilik özellikleri ile teknopedagojik eğitim yeterlikleri arasındaki ilişkinin incelenmesi. İlköğretim Online, 12(3), 1241-1264.

İçen, M., Tuncel, G., \& Özay, C. (2018). Eğitim felsefesinin yansıması olarak öğrencilerin defterlerini çözümleme: Sosyal bilgiler dersi. Turkish Studies, 13(11), 693-705.

İsmailoğlu, S., \& Zorlu, T. (2018). Yapılandırmacı eğitim felsefesinde dersliklerin mekânsal özellikleri üzerine bir değerlendirme: Rize ili örneği. Online Journal of Art and Design, 6(1). 148-173.

Kanatlı, F., \& Schreglman, S. (2014). İlköğretim öğretmenlerinin sahip oldukları eğitim felsefelerine ilişkin algılarının değerlendirilmesi. Gümüşhane Üniversitesi Sosyal Bilimler Enstitüsü Elektronik Dergisi, 5(9), 127-138.

Karadağ, E., Baloğlu, N., \& Kaya, S. (2009). Okul yöneticilerinin eğitim felsefesi akımlarını benimseme düzeylerine ilişkin ampirik bir çalışma. Uludağ Üniversitesi Fen-Edebiyat Fakültesi Felsefe Dergisi, 12, 181-200. 
Koçak, C., Ulusoy, F. M., \& Önen, A. S. (2012). Öğretmen adaylarının kimlik işlevlerinin ve eğitim inançlarının incelenmesi. X. Ulusal Fen Bilimleri ve Matematik Eğitimi Kongresi. Niğde 27-30 Haziran. Türkiye.

Kozikoğlu, İ., \& Erden, R. Z. (2018). Öğretmen adaylarının eğitim felsefesi inançları ile eleştirel pedagojiye ilişkin görüşleri arasındaki ilişkinin incelenmesi. Elementary Education Online, 17(3), 1566-1582.

Kozikoğlu, İ., \& Uygun, N. (2018). Öğretmenlerin benimsedikleri eğitim felsefeleri ile eğitim programı tasarım yaklaşımları arasındaki ilişkinin incelenmesi. Çukurova Üniversitesi Eğitim Fakültesi Dergisi, 47(2), 411-438.

Kumral, O. (2015). Öğretmen adaylarının eğitim felsefeleri: Pamukkale üniversitesi eğitim fakültesi örneği. Hasan Ali Yücel Eğitim Fakültesi Dergisi, 12(2), 59-68.

Livingston, M. J., McClain, B. R., \&DeSpain, B. C. (1995). Assessing the consistency between teachers' philosophies and educational goals. Education, 116(1), 124-130.

Meral, Y. D. (2014). Ortaöğretim matematik ögretmenlerinin eğitim felsefesi görüşleri ve ögretmeögrenme anlayışlarının yapılandırmacı öğrenme ortamı düzenleme becerilerine etkisi (Yayımlanmamış yüksek lisans tezi). Kocaeli ÜniversitesiSosyal Bilimler Enstitüsü, Kocaeli.

Oğuz, A., Altınkurt, Y., Yılmaz, K., \& Hatipoğlu, S. (2014). Öğretmenlerin eğitim inançları ile öğrenen özerkliğini destekleme davranışları arasındaki ilişki. Turkish Journal of Educational Studies, l(1), 37-78.

Ornstein, A. C., \& Hunkins, F. P. (2012). Curriculum: Foundations, principles, and issues, student value edition. New Jersey: Pearson.

Ornstein, C. A., \& Hunkins, P. F. (2016). Curriculum: foundations, principles and issues. USA: PearsonEducation, Inc.

Pajares, F. M. (1992). Teachers' beliefsandeducationalresearch: cleaningup a messyconstruct. Review of Educational Research, 62, 307-332.

Sönmez, V. (2009). Eğitim felsefesi. Ankara: Anı Yayıncılık.

Sönmez, V. (2011). Öğretim ilke ve yöntemleri. Ankara: An1 Yayınc1lı.

Şahin, S., Tunca, N., \& Ulubey, Ö. (2014). Öğretmen adaylarının eğitim inançları ile eleştirel düşünme eğilimleri arasındaki ilişki. Elementary Education Online, 13(4). 1473-1492.

Şişman, M. (2008). Eğitim bilimine giriş. Ankara: Pegem Yayıncılık.

Taşkın, T. (2020). Fizik, Kimya ve Biyoloji öğretmenlerinin eğitim felsefesi tercihlerinin ve bilimsel epistemolojik inançlarının çeşitli değişkenler açısından incelenmesi. Eğitimde Kuram ve Uygulama, 16(1), 1-19.

Tekin, S., \& Üstün, A. (2008). Amasya eğitim fakültesi öğretmen adaylarının eğitim süreci hakkındaki felsefi tercihlerinin tespiti. Selçuk Üniversitesi Ahmet Keleşoğlu Ĕ̆itim Fakültesi Dergisi, 25, $145-158$.

Terzi, A. R. (2010). Eğitim bilimine giriş (2. bask1). Ankara: Detay Yayınc1lık.

Topçu, N. (2014). Türkiye'nin maarif davası. İstanbul: Dergah Yayınları

Tunca, N., Alkın-Şahin, S., \& Oğuz, A. (2015). Öğretmenlerin eğitim inançları ile meslekî değerleri arasındaki ilişki. Kalem Eğitim ve İnsan Bilimleri Dergisi, 5(1), 11-47.

Uğurlu, C. T., \& Çalmaşur, H. (2017). Öğretmenlerin ve öğretmen adaylarının eğitim inançlarına ilişkin görüşleri: bir karma yöntem çalışması. Adlyaman Üniversitesi Sosyal Bilimler Enstitüsü Dergisi, 9(25), 230-273.

Winch, C. (2012). Forphilosophy of education in teacher education. Oxford Review of Education, 38(3), 305322. 
Wiles, J. \&Bondi, J. (2007). Curriculum development: A guide to practice (Seventh Ed.). New Jersey: Pearson Merill Prentice Hall Inc.

Yayla, A. (2009). Eğitimin felsefi temelleri. H. B. Memduhoğlu ve K. Yılmaz (Ed.), Eğitim bilimine giriş (s. 19-43). Ankara: Pegem Akademi.

Yılmaz, K., Altınkurt, Y., \& Çokluk, Ö. (2011). Eğitim inançları ölçeğinin geliştirilmesi: Geçerlik ve

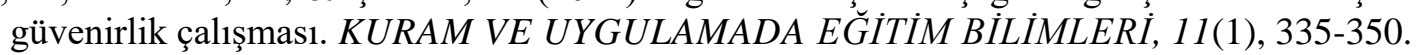

Y1lmaz, K. (2017). Eğitim fakülteleri yeni bir eğitim felsefesi oluşturabilir mi? Türkiye Ĕgitim Dergisi, 2(1), 22-41.

Yokuş, T. (2016). Müzik öğretmeni adaylarının benimsedikleri eğitim felsefelerinin çeşitli değişkenler açısından incelenmesi. Muğla Sıtkı Koçman Üniversitesi Ĕ̆itim Fakültesi Dergisi, 3(1), 26-36.

\section{Extended Abstract}

\section{Introduction}

Through philosophy, we become aware of our beliefs and values while on the other hand, it focuses on the truth as a whole. Education and philosophy comprise a whole. The role of philosophy cannot be ignored while education shapes learning environments. Educational philosophy has the leading role in all different phases of education, starting from the step of defining the goals of an education process. When the related literature is analyzed, it can be seen that educational philosophies adopted by teachers affect the education practiced in classrooms. Different beliefs of teachers may cause differences in the application process of education in classrooms. The purpose of this study is to analyze the educational philosophies adopted by teachers in terms of different variables. The educational philosophies adopted by teachers are observed and the impacts of the variables of gender, faculty, professional seniority, education level, and specialty on the adopted educational philosophy are analyzed in the scope of this study.

\section{Method}

The correlational survey model is used in this study in the scope of the general survey. The study was completed during the first semester of the 2019-2020 academic years. 265 teachers were included in the study through the convenience sampling method. Forms received from these teachers were carefully analyzed, faulty/incomplete forms were eliminated and 240 teachers were finally included in the process. "Education Beliefs Scale" developed by Yılmaz, Altınkurt, and Çokluk (2011) was used as the data collection tool. There are 40 scale items and five sub-dimensions in the scale. These sub-dimensions analyzed in the study are Existentialism, Progressivism, Perennialism, Re-Constructionism, and Essentialism. While analyzing the obtained data, the independent sampling t-test was used to determine the impacts of gender and university variables on adopting an educational philosophy. ANOVA was used to determine the variation in terms of the variables of professional seniority, education level, and specialty.

\section{Results}

The first sub-problem of the study was determining the educational philosophies adopted by teachers. The data about the problem indicated that the teachers included in the study adopted existentialism, progressivism, perennialism, re-constructionism, and essentialism respectively. The second problem of the study was determining if there were variations in the adopted educational philosophies in terms of the variables of faculty, professional seniority, and specialty. The obtained data indicated that there was no meaningful difference in the philosophies of perennialism, progressivism, re-constructionism, and existentialism in terms of the variable of gender. When the data about the variable of faculty was analyzed, it was seen that there was no meaningful difference in the philosophies of perennialism, essentialism, progressivism, and existentialism. However, it was determined that there was a meaningful difference in re-constructionism educational philosophy in favor of the teachers who graduated from education faculty. There were meaningful differences in the adopted educational philosophies among groups in terms of the variable of professional seniority. It was determined that teachers who have experience for 16-20 and more than 21 years generally adopted educational philosophies more and put them into practice. However, it was observed that although there were meaningful differences in terms of the professional seniority among groups, the effect levels were low. When the issue was analyzed in 
terms of the education level of participant teachers, it was seen that university, postgraduate, or doctorate didn't cause any meaningful difference in the adopted educational philosophy. When the issue was analyzed in terms of the variable of specialty, it was observed that classroom teachers adopted the philosophy of existentialism more than the teachers in other specialties.

\section{Discussion}

According to the results of the study process, teachers adopted the philosophy of existentialism the most while they adopted perennialism the least. When the importance of education beliefs of teachers in the education process is taken into consideration, it can be said that the reason why they adopted existentialism and progressivism respectively is that they adopted a constructionist education approach. When the literature about the issue is analyzed, it can be seen that teachers don't have a single philosophical belief; they can reflect more than one education philosophy in the classroom environment. When the gender of teachers was taken into consideration, it was seen that male teachers adopted the essentialism philosophy more. It was seen that the studies in the literature have similar results. Another result of the study indicates that the re-constructionism education philosophy was adopted more by the teachers who graduated from the education faculty. This result may lead us to think that classes of education philosophy, education psychology, critical thinking, and human relations in education faculties directed teachers towards modern education philosophies. It was observed that teachers who have more than 16 years of experience have higher averages in terms of adopting all education philosophies. When the professional seniority of the teachers was analyzed, it was determined that teachers who have more than 6 years of experience adopted all of the educational philosophies more. It was determined that the education level of teachers didn't affect the education philosophy they adopted. This result contradicts the thought that teachers adopt professional values more in line with the increase in their experience and they reflect modern educational philosophies in their classrooms. When the variable of specialty was analyzed, it was determined that classroom teachers adopted the philosophy of existentialism more. According to the literature, there are differences in philosophical beliefs adopted by teachers.

\footnotetext{
* Bu çalışmada bulunan yazarların katkı oranları: Okay DEMIR \%50, Seda AKTI ASLAN \%50
} 